Saudi Journal of Medical and Pharmaceutical Sciences

Abbreviated Key Title: Saudi J Med Pharm Sci ISSN 2413-4929 (Print) |ISSN 2413-4910 (Online) Scholars Middle East Publishers, Dubai, United Arab Emirates Journal homepage: https://saudijournals.com/sjmps

\title{
Preparation and Antifungal Properties of Chalcone and Halogenated Derivatives
}

\author{
Bunu Samuel Jacob ${ }^{1 *}$, Awala Ebisindor Victoria ${ }^{1}$, Eboh Darlington Deboh ${ }^{2}$ \\ ${ }^{1}$ Department of Pharmaceutical and Medicinal Chemistry, Faculty of Pharmacy, Niger Delta University, Wilberforce Island, Amassama, Nigeria \\ ${ }^{2}$ Department of Pharmaceutical Microbiology and Biotechnology, Faculty of Pharmacy, Niger Delta University, Wilberforce Island, Amassama, \\ Nigeria
}

DOI: $10.36348 /$ sjmps.2020.v06i04.009 $\quad$ Received: 10.04.2020 | Accepted: 24.04.2020 | Published: 30.04 .2020

*Corresponding author: Bunu Samuel Jacob

\section{Abstract}

Acetophenone (1-phenylethan-1-one) reacted with benzaldehyde in the presence of acetic acid, potassium hydroxide, and ethanol on an ice bath for 24 hours via the Claisen-Schmidt condensation reaction giving rise to chalcone (2E-1, 3diphenylprop-2-en-1-one). On condensation of acetophenone with chlorinated benzaldehyde gives the halogenated derivatives of chalcone. The products were reduced with hydrogen peroxide and nickel reagent to form the epoxide derivatives of the halogenated chalcones (4-chlorochalcone and 4-chlorochalcone epoxide). Structure elucidation of the synthesized compounds was done using elemental analysis, 1H NMR, 13CNMR, FTIR, TLC, and UV/VIS. Synthesized compounds were obtained in high purity and percentage yield. The microbial activity of the synthesized compounds was studied against some test organisms, Candida albican, Staphylococcus aureus, Escherichia coli, and Pseudomonas aeruginosa. Microbial results showed the synthesized compounds were void of antibacterial activity but showed marked activities against Candida albican. Hence are promising molecules in the combat of fungal infections globally.

Keywords: Halogenated Chalcones, Antifungal, Synthesis, Thin-Layer Chromatography.

Copyright @ 2020: This is an open-access article distributed under the terms of the Creative Commons Attribution license which permits unrestricted use, distribution, and reproduction in any medium for non-commercial use (NonCommercial, or CC-BY-NC) provided the original author and source are credited.

\section{INTRODUCTION}

Microorganisms on daily basis develop resistance to available conventional antimicrobial agents in clinical practice, thus, the need for the search of more active, effective, less toxic and cost-effective alternatives to already existing medications. Much study has been carried out with the sole aim to discover the therapeutic value of chalcones and different derivatives [1-3]. Chalcones constitute one of the important classes of anticancer agents that have shown promising therapeutic efficacy in the management of human cancers and microbial infections. They are considered as the precursors of flavonoids and isoflavonoids and are abundantly available in edible plants. Substituted chalcones have shown a wide variety of activities, such as anticancer, anti-inflammatory, antifungal, antibacterial, antiparasitic, antiulcer and analgesic activities [4-8]. Several modifications on chalcone chromophore have been reported, these include the hydroxyl, methoxy, and amino groups as substituents with promising anticancer activity and antimicrobial activities [9-11]. Notably, the 4, 6diphenyl-2-thiopyrimidine and epoxide derivatives of chalcones had been shown to have remarkable antiinflammatory properties $[12,13]$. These reported properties and the essential role of chalcones derivatives, especially the heterocyclic pyrazoline, pyrimidines halogenated derivatives in the certain biological reaction inspired us to synthesis all these halogenated derivatives of chalcone and further subjected the products for antifungal screening and structural characterization using nuclear magnetic resonance, infra-red spectroscopy, Ultraviolet/Visible spectrophotometry and thin-layer chromatography [14, 15]. Efforts in this study were to synthesize halogenated derivatives of chalcones using the Claisen-Schmidt condensation reaction between different derivatives of halogenated benzaldehyde and acetophenone base with further structural elucidations of the synthesized products that can be used for the formulation of antifungal therapy. 


\section{Synthetic Pathway}

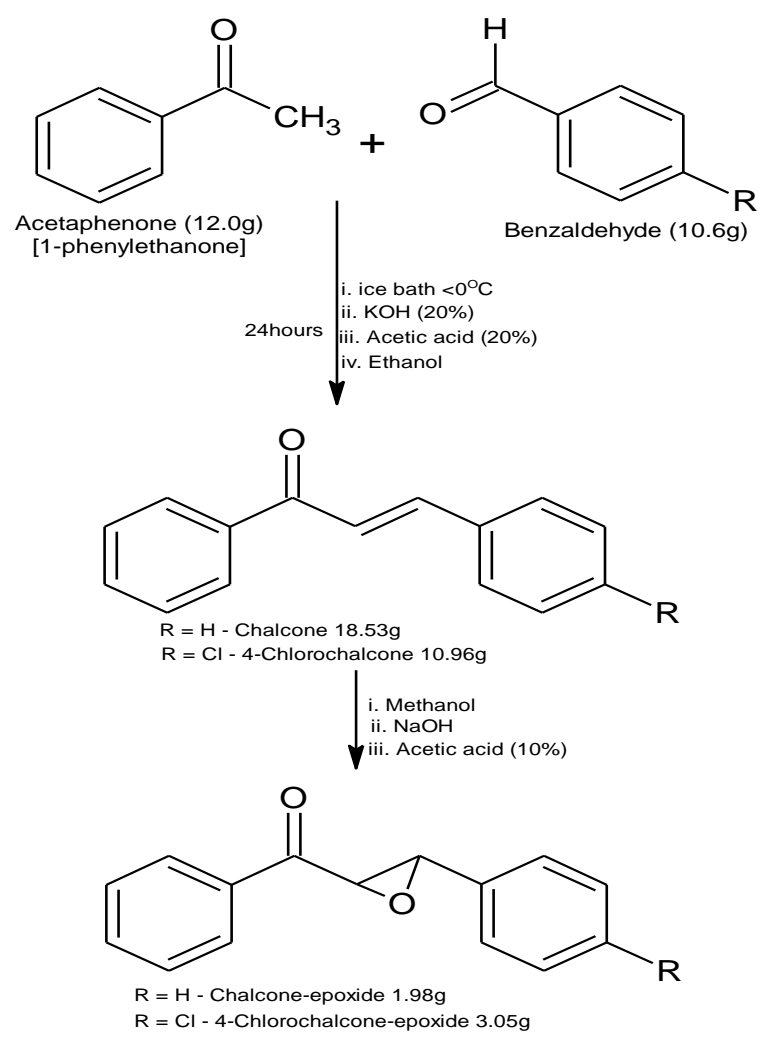

Fig-1: Synthetic pathway of halogenated chalcones (ChemSketch software)

\section{Materials AND MethodS \\ MATERIALS}

Acetophenone, benzaldehyde, p-chlorobenzaldehyde, ethyl acetate, petroleum spirit, dimethyl sulfoxide, ethanol, potassium hydroxide, acetic acid, and methanol were procured from BDH chemicals, England. The microbial cultures were obtained from the Faculty of Pharmacy, Niger Delta University. The melting point was quantified with the Gallen-Kamp melting point apparatus while Nuclear Magnetic Resonance and IR data were performed on a $400 \mathrm{MHz}$ instrument, (Varian Inc. Palo Alto, California, USA) and FTIR-8400S equipment (Shimadzu global links, North America).

\section{Preparation}

In the synthesis of chalcone, $10.6 \mathrm{~g}$ and $12.0 \mathrm{~g}$ of Benzaldehyde and acetophenone respectively were condensed (Claisen-Schmidt condensation) in a round bottom flask inclosing ethanol, $25 \mathrm{~mL}$, stirred on an ice bath below $0^{\circ} \mathrm{C}$. $20 \mathrm{mmL}$ of Potassium hydroxide $(20 \%)$ was added to the mixture in a drop-wise manner using a burette while the stirring continuous for 15-20 minutes, the mixture was allowed to stand for 24 hours and ice chips were added and were acidified with $25 \mathrm{~mL}$ of cold acetic acid $(20 \%)$, by titration, resulting in the formation of some precipitate that was filtered under suction and recrystallized in ethanol medium to get the pure sample (chalcone). It was then air dried, weighed and the melting point was determined. This same procedure was used in the preparation of 4-chlorochalcone (halogenated chalcone) using 4-chlorobenzaldehyde $(7.02 \mathrm{~g})$ and acetophenone $(6.0 \mathrm{~g})$. The above products were oxidized in the presence of methanol $(60 \mathrm{~mL}), 10 \%$ of sodium hydroxide $(10 \mathrm{~mL}), 10 \%$ acetic acid $(20 \mathrm{~mL})$ respectively. This resulted in chalcone epoxide and 4-chlorochalcone epoxide. The products were purified using the above methods.

\section{Elemental analysis (Chromatographic analysis, FTIR, NMR, and UV/VIS)}

Ethyl acetate and petroleum spirit were used as the solvent system in a 3:7 ratio. TLC chromatograms were activated in an oven for 5 minutes. The tank was allowed to saturate and the synthesized products were spotted against the starting material after dissolving in methanol. The solvent system was allowed to move upwards until it gets to the solvent. The plate was carefully removed and viewed either under UV lamb or an iodine tank (were spots were not visible under UV lamb) and $\mathrm{R}_{\mathrm{f}}$ values were determined. The compounds were further subjected to IR, 1HNMR, $13 \mathrm{CNMR}$ and UV spectroscopic analysis in a bid to elucidate their structural components and functional groups. 


\section{Test Organisms}

The test organisms cultures isolates (Candida albican, Escherichia coli, Pseudomonas aeruginosa, and Staphylococcus aureus), were obtained from the microbial bank of the Department of Pharmaceutical Microbiology and Biotechnology, Faculty of Pharmacy, Niger Delta University, Nigeria. The bacterial isolates were standardized by colony suspension and matching the strain's suspension with $0.5 \mathrm{McF}$ arland standard to give a final concentration of $1.5 \mathrm{x}$ $10^{8} \mathrm{cfu} / \mathrm{mL}$

\section{Determination of Zone of Inhibition (ZI)}

The zones of inhibition were measured in millimeters and compared with the control standards using the method described by Bonev et al., [16]. The antibiotic susceptibility testing was determined using Kirby-Bauer modified diffusion technique, which involves swabbing Mueller-Hinton agar (MHA), plates with the resultant saline suspension of each strain and six wells were aseptically bored using size $6 \mathrm{~mm}$ cork borer on the agar surfaces seeded with the test organisms. The wells were sealed at the bottom with molten sterilized agar. Stock solutions of the synthesized compounds were prepared by dissolving $500 \mathrm{mg}$ of each in $5 \mathrm{~mL}$ DMSO to give a concentration of $100000 \mathrm{mcg} / \mathrm{mL}$. Then $0.1,0.05,0.025$ and $0.0125 \mathrm{~mL}$ of the stock corresponding to $10000,5000,2500$ and $1250 \mathrm{mcg} / \mathrm{mL}$ respectively, of the synthesized compounds were aseptically introduced into the agar wells, and same concentrations of ketoconazole antifungal standard were prepared aseptically and transferred to the wells. The gentamicin and ciprofloxacin antibacterial discs were also placed on the agar surface. The plates were left undisturbed on the bench for 30 minutes to enable the agar to absorb the compounds adequately, incubated for 24 hours at $37^{\circ} \mathrm{C}$ and observed for confluent growth of the microorganisms and clear zones of inhibition around the samples in the agar wells.

\section{Data Analysis}

Data were analyzed with Graphpad Instat version 3.0 statistical software. All analyzed data were expressed as mean \pm standard deviations (SDs). One-way ANOVA and Tukey-Kramer multiple comparisons test were performed to analyze the differences between test and control groups $(\mathrm{P}<0.05)$.

\section{RESULTS}

The prepared compounds were analyzed chemically with TLC, FTIR, and NMR while biological assay was carried out with microorganisms as shown in the tables below.

Table-1: Prepared Chalcone and derivatives physicochemical and elemental analysis

\begin{tabular}{|c|c|c|c|c|}
\hline Sample & Chalcone & 4-chloro-chalcone & Chalcone-epoxide & $\begin{array}{l}\text { 4-chloro-chalcone- } \\
\text { epoxide }\end{array}$ \\
\hline Structure & & & & \\
\hline IUPAC name & $\begin{array}{l}\text { (2E)-1,3-diphenylprop-2- } \\
\text { en-1-one }\end{array}$ & $\begin{array}{l}\text { (2E)-3-(4- } \\
\text { chlorophenyl)-1- } \\
\text { phenylprop-2-en-1-one }\end{array}$ & $\begin{array}{l}\text { Phenyl(3- } \\
\text { phenyloxiran-2-yl) } \\
\text { methanone] }\end{array}$ & $\begin{array}{l}\text { [3-(4- } \\
\text { chlorophenyl)oxiran- } \\
2-y l](\text { phenyl) } \\
\text { methanone }\end{array}$ \\
\hline Yield $(\%)$ & $18.53 \mathrm{~g}(89.10)$ & $10.96 \mathrm{~g}(90.38)$ & $1.98 \mathrm{~g}(44.20)$ & $3.05 \mathrm{~g}(58.90)$ \\
\hline Melting point & $43-47^{\circ} \mathrm{C}$ & $90-99^{\circ} \mathrm{C}$ & $64-68^{\circ} \mathrm{C}$ & $54-58^{\circ} \mathrm{C}$ \\
\hline Rf value & 0.69 & 0.56 & 0.72 & 0.64 \\
\hline TLC spots & 1 & 1 & 1 & 1 \\
\hline \multicolumn{5}{|c|}{ FTIR (KBr) - Peak, intensity $\left(\mathrm{cm}^{1}{ }^{1}\right)$} \\
\hline $\mathrm{C}=\mathrm{O}$ & $1654.9(22.62)$ & $1645.33(35.6)$ & $1681.98(34.1)$ & $1656.91(36.57)$ \\
\hline $\mathrm{C}=\mathrm{C}(\mathrm{Ar})$ & $1589.4(10.22)$ & $1543.1(21.7)$ & $1575.89(48.96)$ & $1579.75(40.62)$ \\
\hline $\begin{array}{l}\mathrm{C}=\mathrm{C} \\
\text { (Alkene/alkane) }\end{array}$ & $3055.35(16.4)$ & $3084.28(22.7)$ & $3045.70(44.32)$ & $3059.2(38.23)$ \\
\hline $\mathrm{C}-\mathrm{Cl}$ & - & $792.77(45.34)$ & - & $698.25(43.71)$ \\
\hline $\mathrm{C}-\mathrm{O}$ & - & - & $1236.41(46.37)$ & $1093.67(44.82)$ \\
\hline $\begin{array}{l}{ }^{1} \mathrm{HNMR} \text { (DMSO } \\
\text { d }_{6} \text { ) } \delta \text { ppm }\end{array}$ & $\begin{array}{l}7.45(\mathrm{t}, \mathrm{j}=2 \mathrm{H}, \mathrm{Ar}-\mathrm{H}, \mathrm{gg}) \\
7.57(\mathrm{t}, \mathrm{j}=2 \mathrm{H}, \mathrm{Ar}-\mathrm{H}, \mathrm{ff}) \\
7.65-7.69 \quad(\mathrm{~m}, 2 \mathrm{H}, \mathrm{Ar}-\mathrm{H}, \\
\mathrm{ee})\end{array}$ & $\begin{array}{l}7.52-8.17 \quad(\mathrm{~d}, \quad \text { Ar-H }) \\
6.7-6.9(\mathrm{~d}, \mathrm{HC}-\mathrm{C}) .\end{array}$ & $\begin{array}{l}4.15(\mathrm{~d}, \mathrm{j}=4 \mathrm{~Hz}, \mathrm{H}- \\
\mathrm{CO}) ; \\
4.83(\mathrm{~d}, \mathrm{j}=4 \mathrm{~Hz}, \mathrm{H}- \\
\mathrm{CO}) ;\end{array}$ & $\begin{array}{l}3.34(\mathrm{~s}, \mathrm{HC}-\mathrm{O}) \\
3.82(\mathrm{~s}, \mathrm{HC}-\mathrm{O}) \\
7.4-8.03(\mathrm{Ar}-\mathrm{H})\end{array}$ \\
\hline
\end{tabular}


Bunu Samuel Jacob et al; Saudi J Med Pharm Sci, April., 2020; 6(4): 379-389

\begin{tabular}{|c|c|c|c|c|}
\hline & $\begin{array}{l}7.74-7.78(\mathrm{~d}, \mathrm{j}=15.6,1 \mathrm{H}, \\
=\mathrm{CH}, \mathrm{d}) ; \\
7.88-7.90(\mathrm{~m}, 2 \mathrm{H}, \mathrm{Ar}-\mathrm{H}, \\
\text { aa); } \\
7.93-7.97(\mathrm{~d}, \mathrm{j}=15.6,1 \mathrm{H}, \\
=\mathrm{CH}, \mathrm{e}) ; \\
8.15-8.17(\mathrm{~m}, 2 \mathrm{H}, \mathrm{Ar}-\mathrm{H}, \\
\text { bb) }\end{array}$ & & $7.39-8.03(\mathrm{Ar}-\mathrm{H})$ & \\
\hline \multicolumn{5}{|c|}{${ }^{13}$ CNMR (DMSO d $\left.{ }_{6}\right) \delta p p m$} \\
\hline $\mathrm{Ar}-\mathrm{C}=\mathrm{C}$ & $129-138$ & $110-130$ & $126-137$ & $128-135$ \\
\hline Alkene $-\mathrm{C}=\mathrm{C}$ & 144 & 140 & - & - \\
\hline $\mathrm{C}=\mathrm{O}$ & 190 & 190 & 193 & 198 \\
\hline $\mathrm{C}-\mathrm{O}$ & - & - & $56-60$ & $58-60$ \\
\hline $\begin{array}{l}\text { UV-VISIBLE } \\
\text { (Methanol) } \\
\lambda \max \end{array}$ & & & & $\begin{array}{l}452.00-0.153 \\
432.00-0.070 \\
342.00-0.262 \\
252.00-0.213\end{array}$ \\
\hline
\end{tabular}

${ }^{1}$ HNMR and 13CNMR Spectrum of Synthesized Compounds

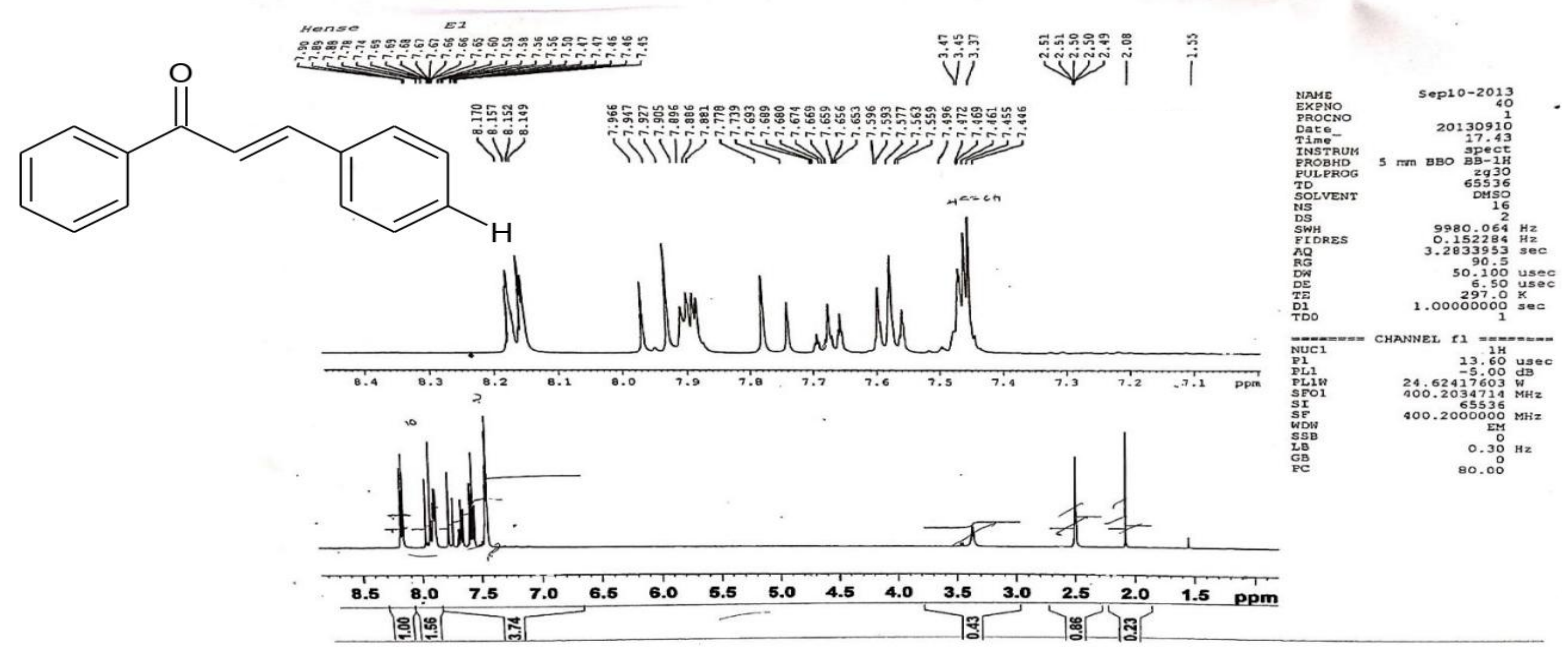

Fig-2: ${ }^{1}$ HNMR Chalcone

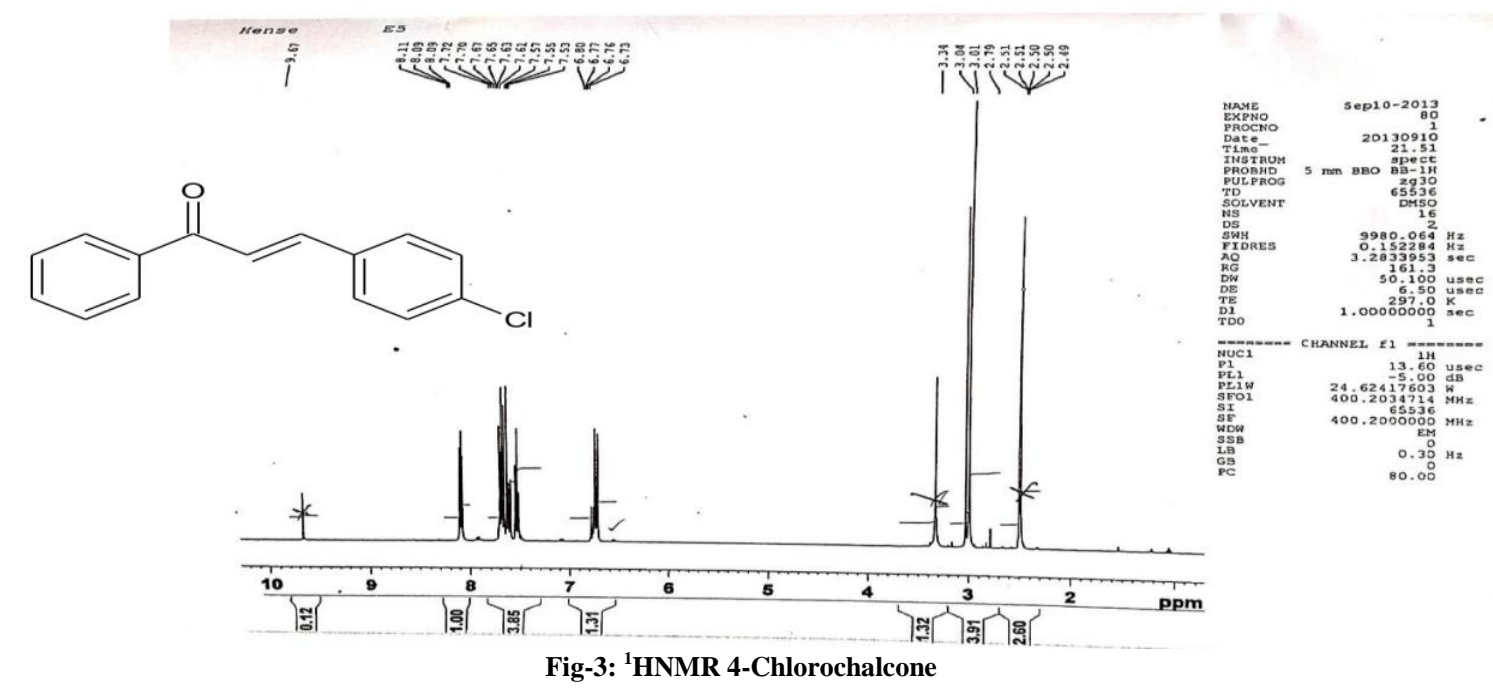



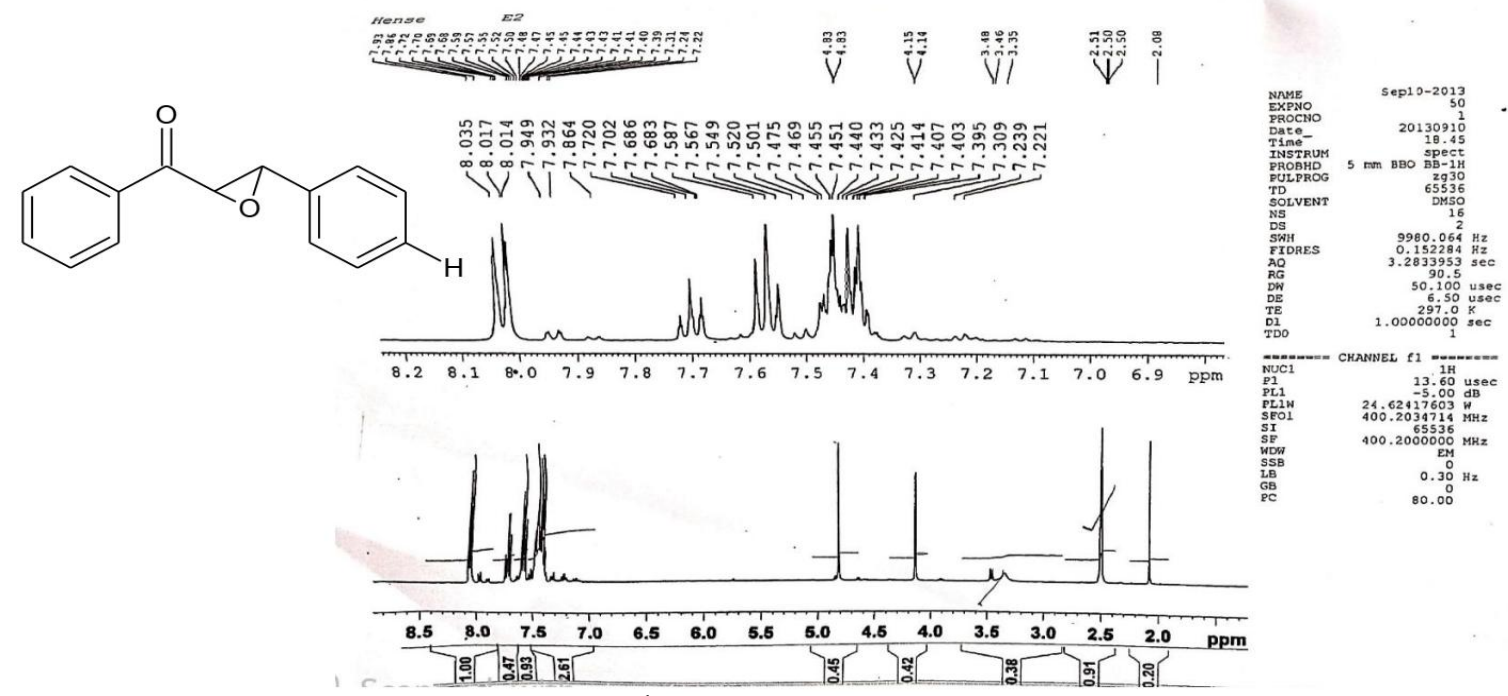

Fig-4: ${ }^{1}$ HNMR Chalcone-epoxide<smiles></smiles>
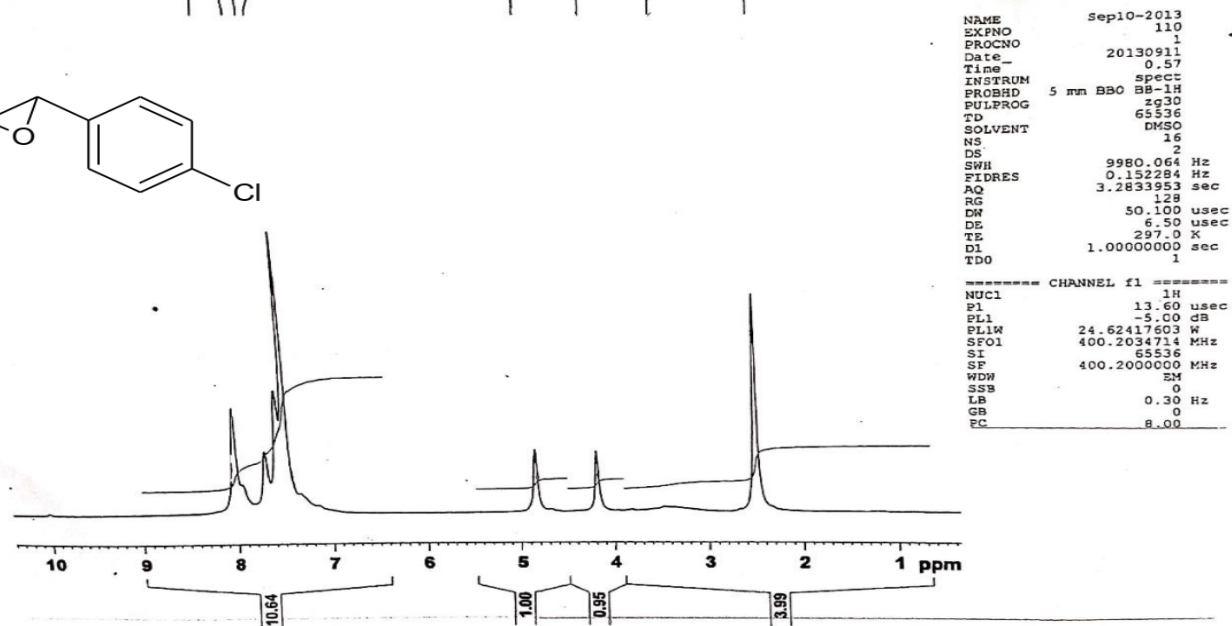

Fig-5: ${ }^{1}$ HNMR 4-Chlorochalcone-epoxide
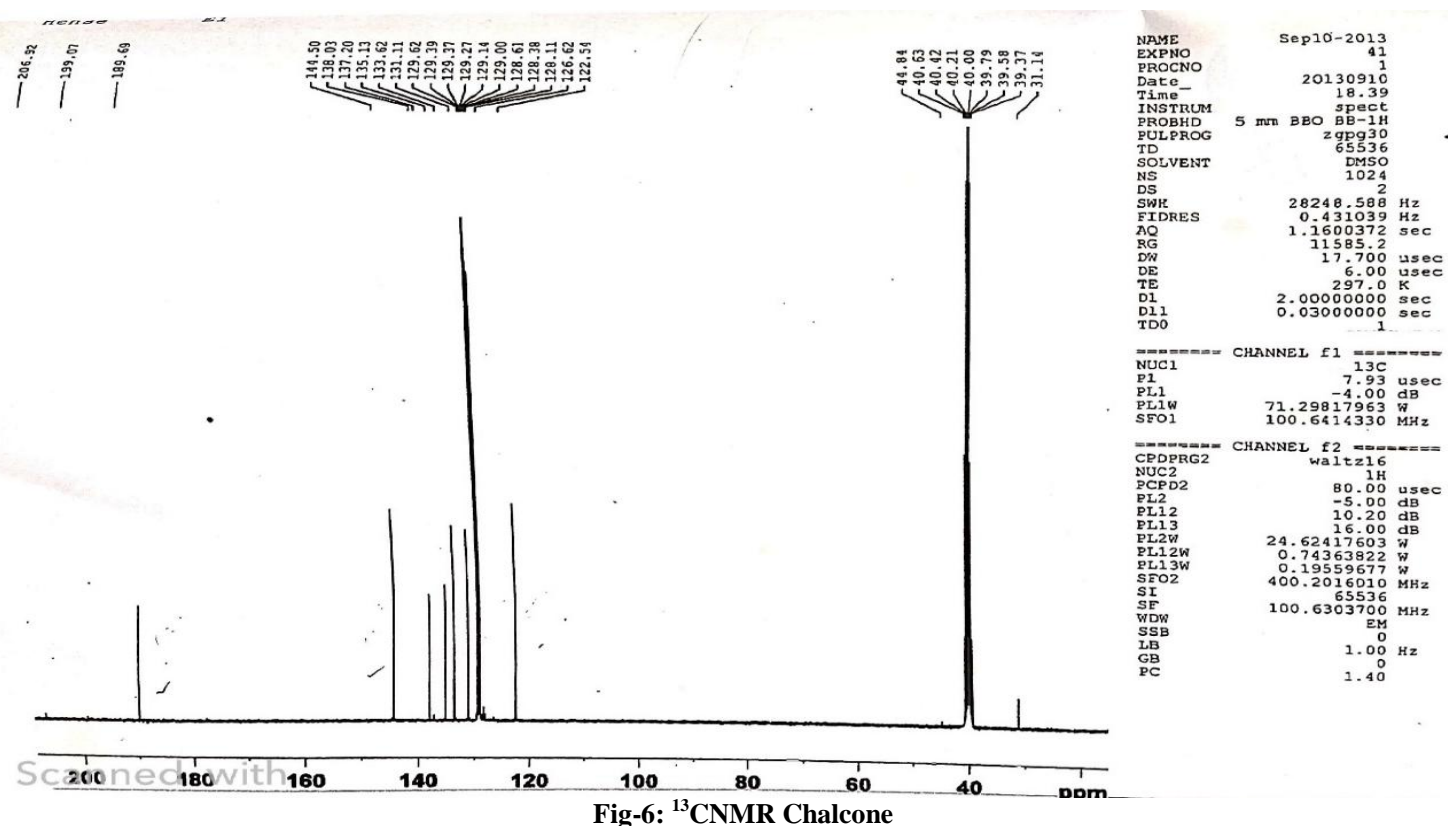
Bunu Samuel Jacob et al; Saudi J Med Pharm Sci, April., 2020; 6(4): 379-389

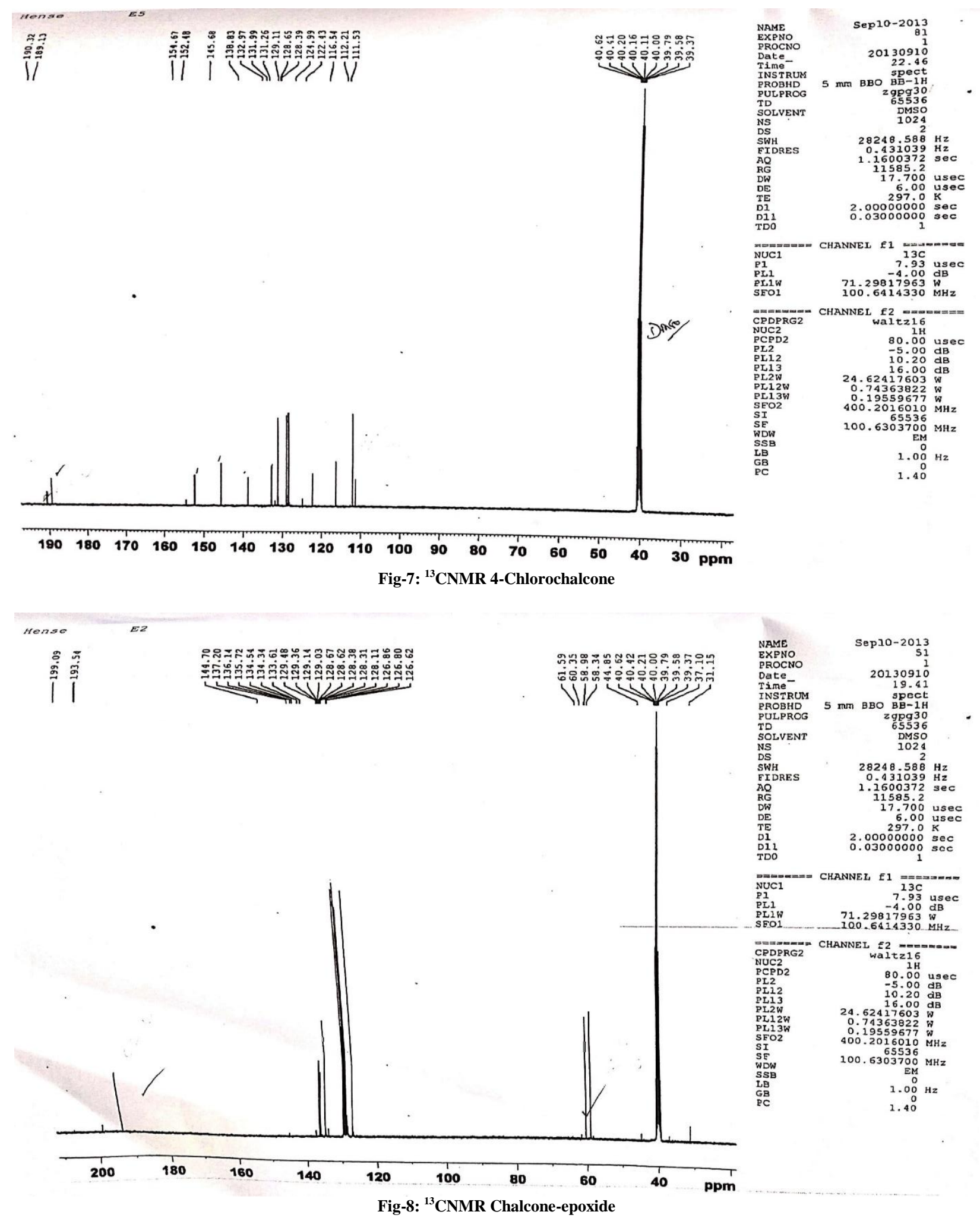




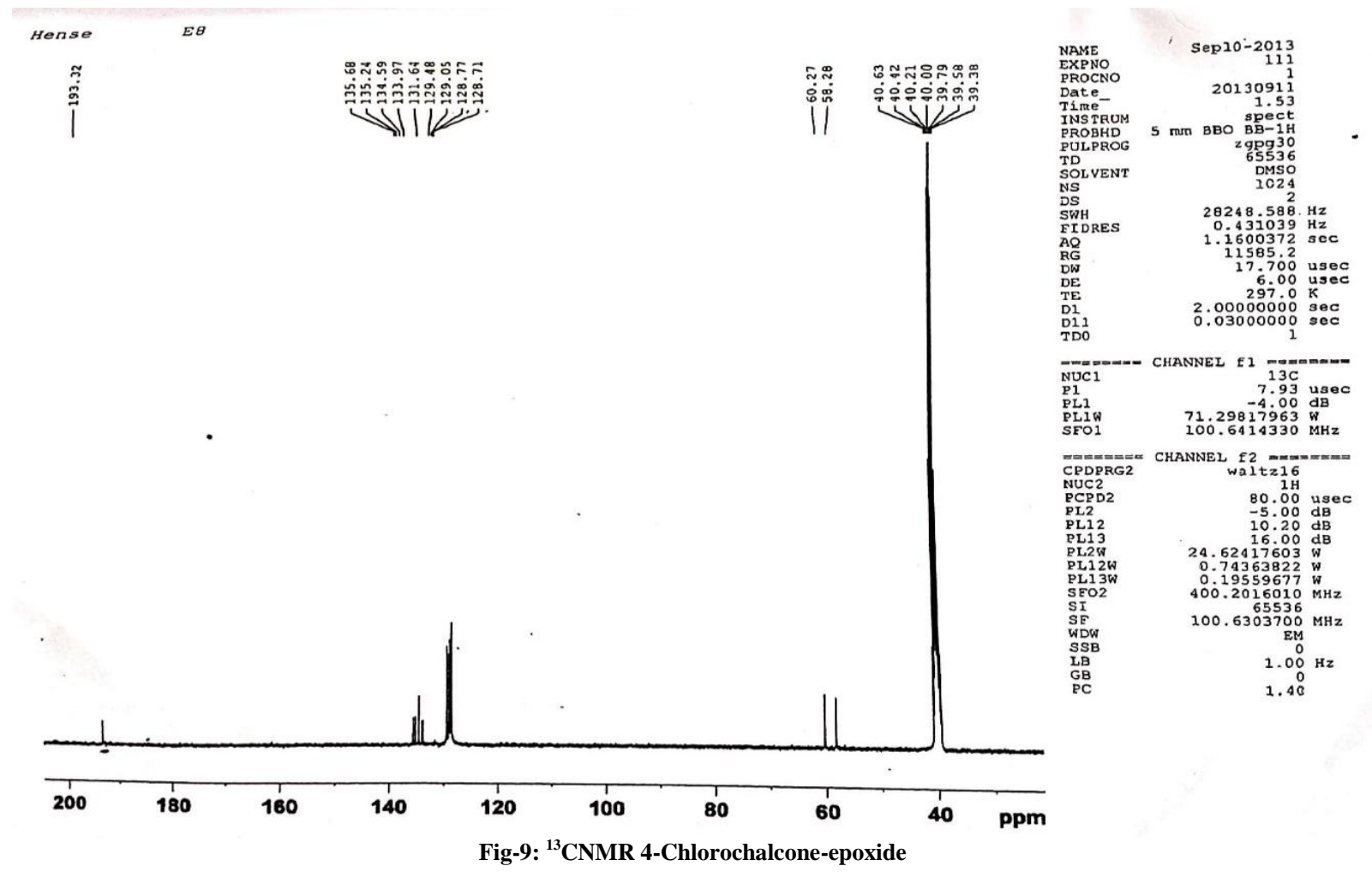

FTIR ANALYSIS RESULT NARICT,ZARIA

由 รHIMADZU

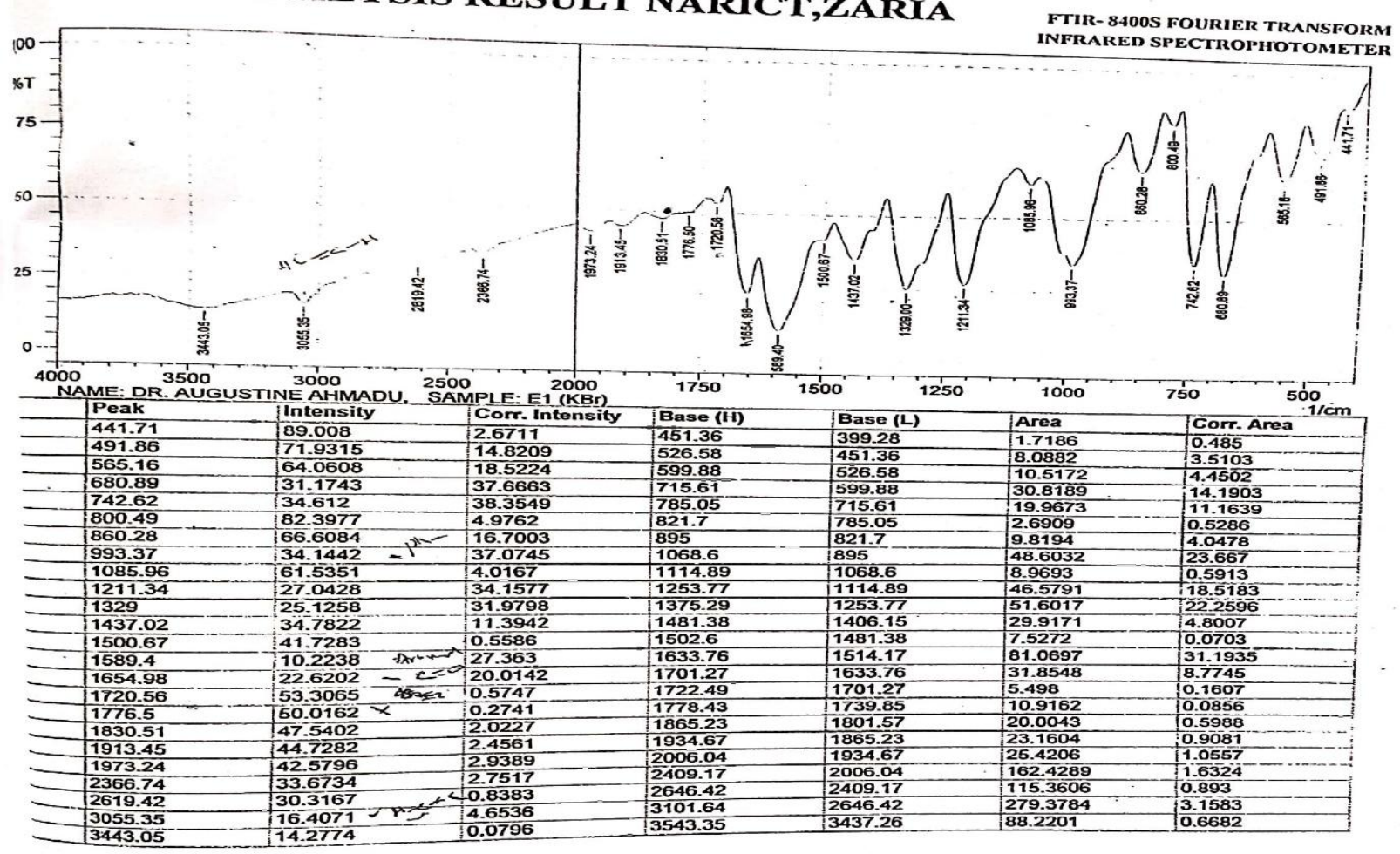

Fig-10: FTIR - Chalcone 


\section{D 由}

FTIR ANALYSIS RESULT NARICT,ZARIA

FTIR- 8400S FOURIEI TRANSFORM

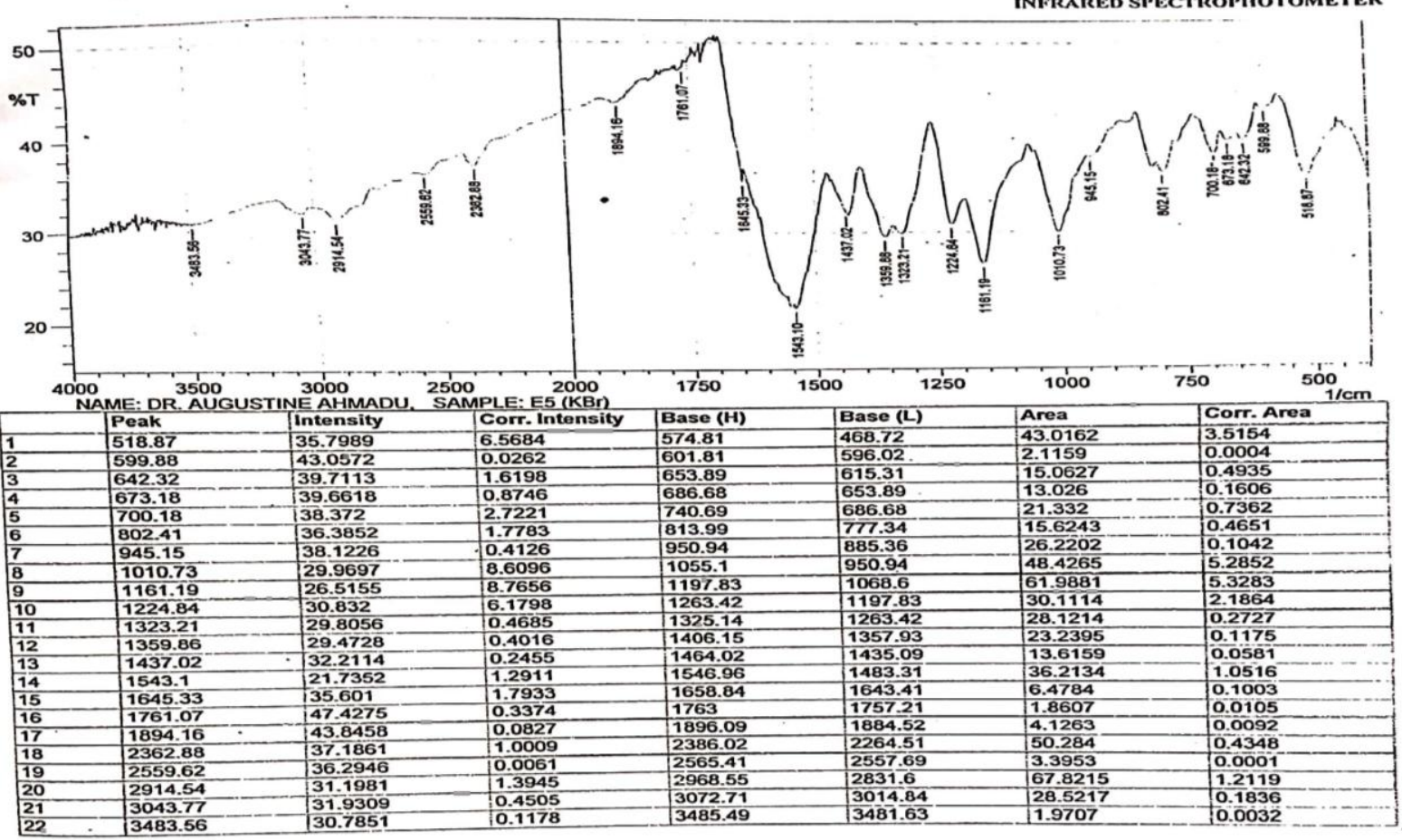

Fig-11: FTIR - 4-Chlorochalcone

Chalome epoxide 由SHIMADZU

FTIR ANALYSIS RESULT NARICT,ZARIA

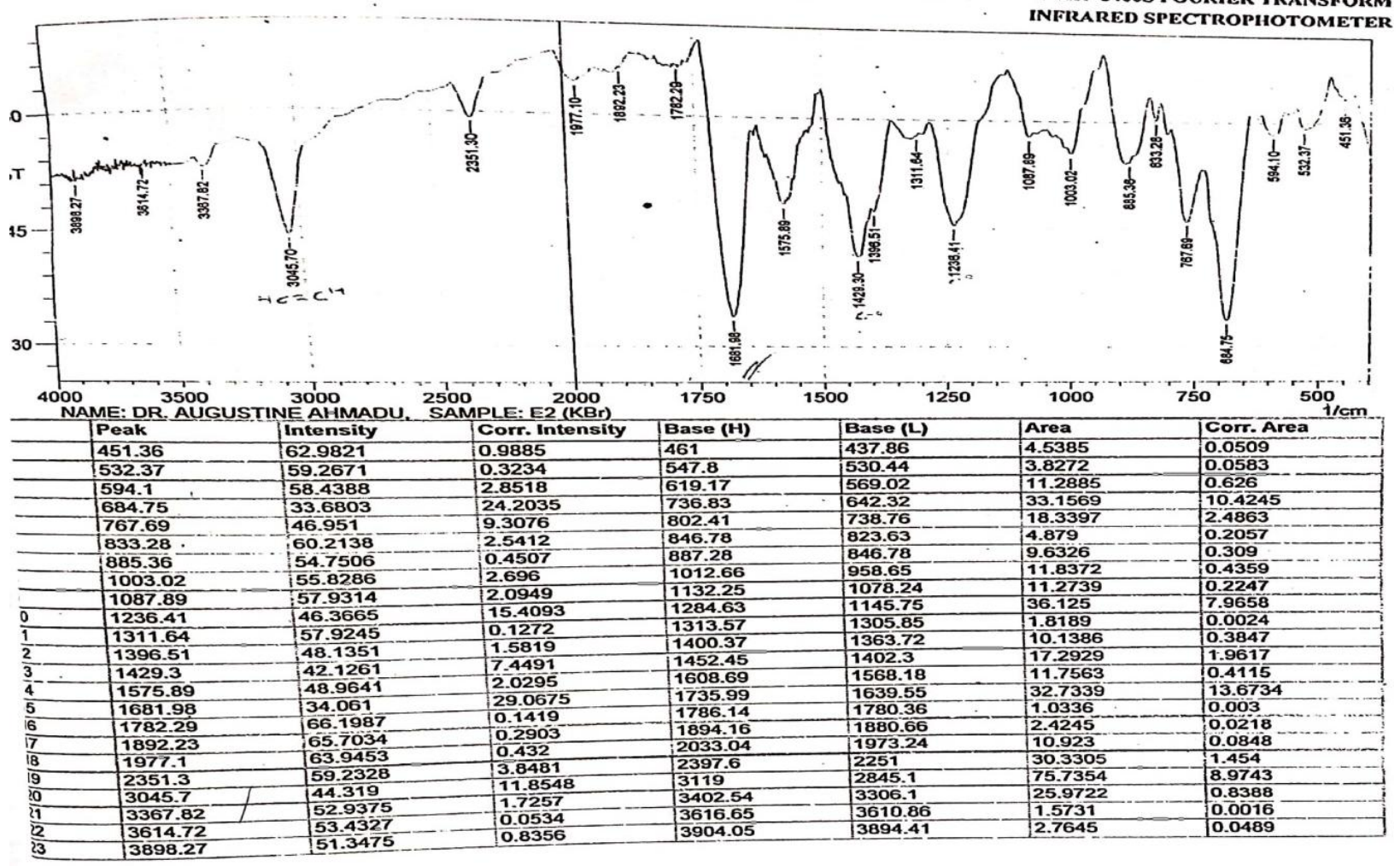

Fig-12: FTIR - Chalcone-epoxide 
FTIR ANALYSIS RESULT NARICT,ZARIA

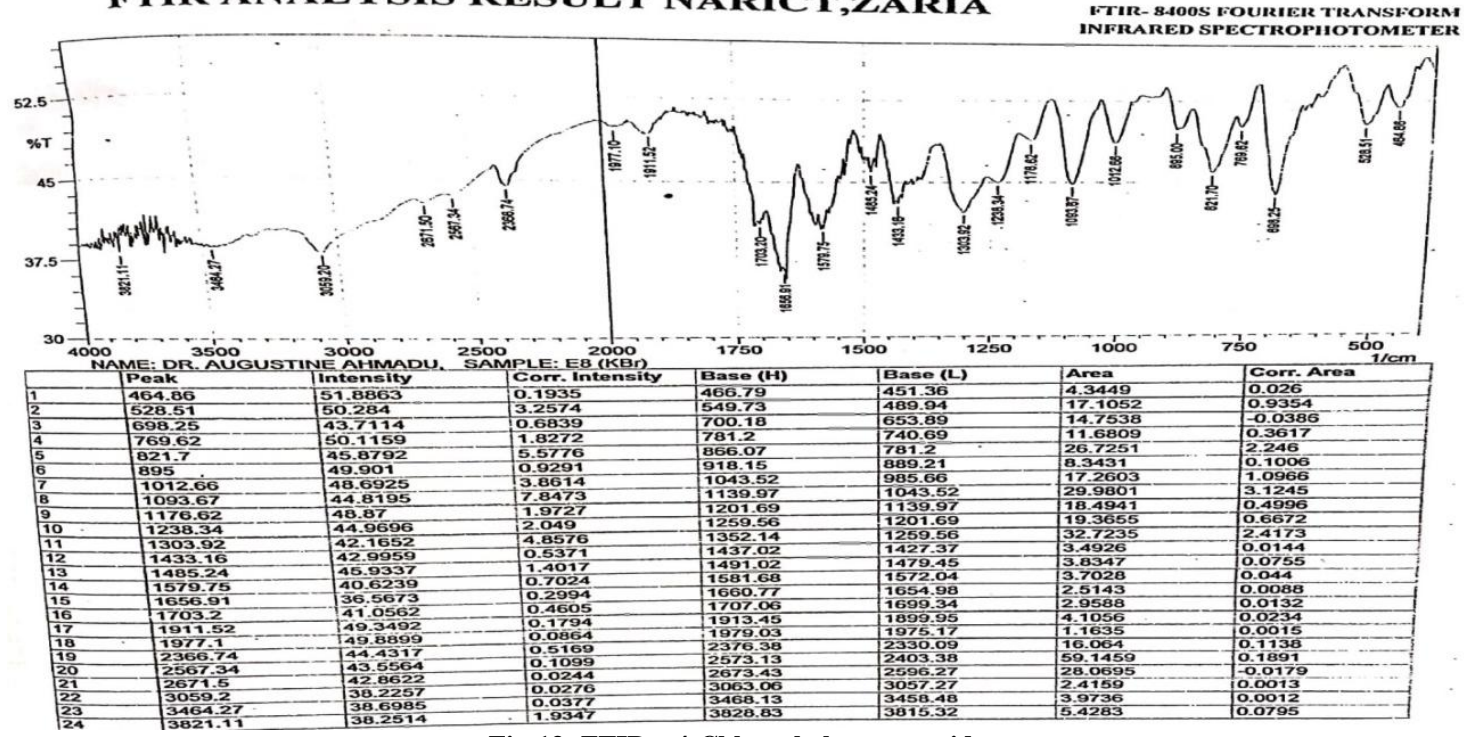

Fig-13: FTIR - 4-Chlorochalcone-epoxide

Table-2: Zone of inhibition of standard drugs used for the microbiological assay

\begin{tabular}{|c|c|c|c|c|c|}
\hline \multirow[t]{2}{*}{ Standard samples } & \multirow[t]{2}{*}{$\begin{array}{l}\text { Concentration } \\
(\mathrm{mcg} / \mathrm{ml})\end{array}$} & \multicolumn{4}{|c|}{$\begin{array}{l}\text { Zone of inhibition }(\mathrm{mm}) \\
\text { Mean } \pm \text { SD }\end{array}$} \\
\hline & & Candida albican & Eserichia coli & $\begin{array}{l}\text { Pseudomonas } \\
\text { aeruginosa }\end{array}$ & Staphylococcus aureus \\
\hline \multirow[t]{4}{*}{ Ketoconazole } & 10,000 & $10.0 \pm 0.71$ & $0.0 \pm 0.0$ & $0.0 \pm 0.0$ & $5.40 \pm 1.14$ \\
\hline & 5,000 & $0.0 \pm 0.0$ & $0.0 \pm 0.0$ & $0.0 \pm 0.0$ & $0.0 \pm 0.0$ \\
\hline & 2,500 & $0.0 \pm 0.0$ & $0.0 \pm 0.0$ & $0.0 \pm 0.0$ & $0.0 \pm 0.0$ \\
\hline & 1,250 & $0.0 \pm 0.0$ & $0.0 \pm 0.0$ & $0.0 \pm 0.0$ & $0.0 \pm 0.0$ \\
\hline Ciprofloxacin & 10 & $0.0 \pm 0.0$ & $40.0 \pm 1.58$ & $40.0 \pm 1.52$ & $24.4 \pm 1.52$ \\
\hline Gentamycin & 10 & $0.0 \pm 0.0$ & $22.8 \pm 2.28$ & $0.0 \pm 0.0$ & $12.4 \pm 1.14$ \\
\hline Control $\left(\mathrm{H}_{2} \mathrm{O}\right)$ & & $0.0 \pm 0.0$ & $0.0 \pm 0.0$ & $0.0 \pm 0.0$ & $0.0 \pm 0.0$ \\
\hline
\end{tabular}

The above shows the zone of inhibition of the standard antimicrobial agents obtained from the microbial bank of the Department of Pharmaceutical
Microbiology and Biotechnology, Niger Delta University.

Table-3: Zone of inhibition of test samples

\begin{tabular}{|l|l|l|l|l|l|}
\hline Test samples & $\begin{array}{l}\text { Conc. } \\
(\mathbf{m c g} / \mathbf{m l})\end{array}$ & $\begin{array}{l}\text { Zone of inhibition } \mathbf{( m m )} \\
\text { Mean } \pm \text { SD }\end{array}$ & \multicolumn{2}{l|}{} \\
\cline { 3 - 6 } & & Candida albican & Eserichia coli & $\begin{array}{l}\text { Pseudomonas } \\
\text { aeruginosa }\end{array}$ & \\
\hline Chalcone & 10,000 & $0.0 \pm 0.0$ & $0.0 \pm 0.0$ & $0.0 \pm 0.0$ & $0.0 \pm 0.0$ \\
\hline & 5,000 & $0.0 \pm 0.0$ & $0.0 \pm 0.0$ & $0.0 \pm 0.0$ & $0.0 \pm 0.0$ \\
\hline & 2,500 & $0.0 \pm 0.0$ & $0.0 \pm 0.0$ & $0.0 \pm 0.0$ & $0.0 \pm 0.0$ \\
\hline & 1,250 & $0.0 \pm 0.0$ & $0.0 \pm 0.0$ & $0.0 \pm 0.0$ & $0.0 \pm 0.0$ \\
\hline 4-chloro-chalcone & 10,000 & $0.0 \pm 0.0$ & $0.0 \pm 0.0$ & $0.0 \pm 0.0$ & $0.0 \pm 0.0$ \\
\hline & 5,000 & $0.0 \pm 0.0$ & $0.0 \pm 0.0$ & $0.0 \pm 0.0$ & $0.0 \pm 0.0$ \\
\hline & 2,500 & $0.0 \pm 0.0$ & $0.0 \pm 0.0$ & $0.0 \pm 0.0$ & $0.0 \pm 0.0$ \\
\hline & 1,250 & $0.0 \pm 0.0$ & $0.0 \pm 0.0$ & $0.0 \pm 0.0$ & $0.0 \pm 0.0$ \\
\hline Chalcone-epoxide & 10,000 & $0.0 \pm 0.0$ & $0.0 \pm 0.0$ & $0.0 \pm 0.0$ & $0.0 \pm 0.0$ \\
\hline & 5,000 & $0.0 \pm 0.0$ & $0.0 \pm 0.0$ & $0.0 \pm 0.0$ & $0.0 \pm 0.0$ \\
\hline & 2,500 & $0.0 \pm 0.0$ & $0.0 \pm 0.0$ & $0.0 \pm 0.0$ & $0.0 \pm 0.0$ \\
\hline & 1,250 & $0.0 \pm 0.0$ & $0.0 \pm 0.0$ & $0.0 \pm 0.0$ & $0.0 \pm 0.0$ \\
\hline $\begin{array}{l}\text { 4-chloro-chalcone } \\
\text { epoxide }\end{array}$ & 10,000 & $\mathbf{2 4 . 2} \pm \mathbf{0 . 8 3}$ & $0.0 \pm 0.0$ & $0.0 \pm 0.0$ & $\mathbf{1 3 . 4} \pm \mathbf{0 . 1 4}$ \\
\hline & & & & & \\
\hline & 5,000 & $\mathbf{1 8 . 4} \pm \mathbf{1 . 1 4}$ & $0.0 \pm 0.0$ & $0.0 \pm 0.0$ & $0.0 \pm 0.0$ \\
\hline & 2,500 & $0.0 \pm 0.0$ & $0.0 \pm 0.0$ & $0.0 \pm 0.0$ & $0.0 \pm 0.0$ \\
\hline & 1,250 & $0.0 \pm 0.0$ & $0.0 \pm 0.0$ & $0.0 \pm 0.0$ & $0.0 \pm 0.0$ \\
\hline
\end{tabular}

$\mathrm{mcg}=$ microgram, $\mathrm{ml}=$ milliliter, $\mathrm{mm}=$ millimeter, $\mathrm{SD}=$ Standard deviation, Conc. $=$ concentration . 
The above shows the zone of inhibition of the synthesized Chalcone and halogenated derivatives at $\mathrm{P}$ value $<0.05$. The test $\mathrm{p}$-value was $<0.001$ from one way ANOVA, which is considered extremely significant. ANOVA assumed that data are sampled from populations with identical standard deviations.

\section{DISCUSSION}

In this research, we synthesized chalcone and three substituted derivatives by the scheme illustrated in Figure-1. The test compounds were synthesized in a good percentage of yield and the physical and analytical determination was done by quantifying their various melting points, purified by Thin-Layer Chromatography, and the structural elucidation with the aid of FTIR, ${ }^{1} \mathrm{HNMR},{ }^{13} \mathrm{CNMR}$ and UV spectrophotometric data. The scheme of the reaction was completed within 24 hours which was ascertained from the TLC single spots for the synthesized compounds. After completion of reaction and workup, the products were identified and characterized using FTIR, ${ }^{1} \mathrm{HNMR},{ }^{13} \mathrm{CNMR}$ and UV spectrophotometric techniques and their structures were elucidated as chalcone, chalcone-epoxide, 4-chlorochalcone, and 4chlorochalcone-epoxide respectively.

Antimicrobial screening of the synthesized compounds against different strains of Gram-positive and Gram-negative bacteria and Candida albican (fungus). 4-chlorochalcone epoxide showed marked inhibition of both Staphylococcus aureus and Candida albican. The other compounds were void of both antibacterial and antifungal activity compared with the standard drugs. This is in line with a report on chalcone derivatives by Ere et al., and Awala et al., respectively $[12,17]$. Hence this is a (halogenated chalcones) promising lead molecule that can be further modified to achieve a variety of antifungal agents, which are very few in contemporary clinical practice. Candida albican, from test results, showed more susceptibility to the synthesized compound (4-chlorochalcone epoxide) than the standard Ketoconazole antifungal agents.

\section{Conclusion}

This study reveals the level of antimicrobial resistance to antifungal agents by microorganisms and, thus paved the pathway to explore more active and effective antifungal agents using the halogenated chalcones as lead compounds.

\section{Conflict of interest: No conflict of interest}

\section{ACKNOWLEDGMENTS}

Special thanks to Prof. Usifoh O. Cyril, Prof. Oluwadiya O. James, Prof Ebeshi U. Benjamin, and Dr. Onanuga Adebola.

\section{Funding: No external funding}

\section{Authors' Contributions}

The study was designed and performed by Dr. Bunu Samuel J, and Pharm. Awala Ebisindor V, while Pharm. Eboh Darlington D. joined in the antimicrobial screening. The article was written by Dr. Bunu Samuel J.

\section{REFERENCES}

1. Park, E. J., Park, H. R., Lee, J. S., \& Kim, J. (1998). Licochalcone A: An Inducer of Cell Differentiation and Cytotoxic Agent from Pogostemon cabling1. Planta medica, 64(05), 464-466.

2. Ko, H. H., Tsao, L. T., Yu, K. L., Liu, C. T., Wang, J. P., \& Lin, C. N. (2003). Structureactivity relationship studies on chalcone derivatives: the potent inhibition of chemical mediators release. Bioorganic \& medicinal chemistry, 11(1), 105-111.

3. Nielsen, S. F., Christensen, S. B., Cruciani, G., Kharazmi, A., \& Liljefors, T. (1998). Antileishmanial chalcones: Statistical design, synthesis, and three-dimensional quantitative structure- activity relationship analysis. Journal of Medicinal Chemistry, 41(24), 4819-4832.

4. Liu, X. L., Xu, Y. J., \& Go, M. L. (2008). Functionalized chalcones with basic functionalities have antibacterial activity against drug sensitive Staphylococcus aureus. European journal of medicinal chemistry, 43(8), 1681-1687.

5. Ares, J. J., Outt, P. E., Randall, J. L., Johnston, J. N., Murray, P. D., O'Brien, L. M., ... \& Ems, B. L. (1996). Synthesis and biological evaluation of flavonoids and related compounds as gastroprotective agents. Bioorganic \& Medicinal Chemistry Letters, 6(8), 995-998.

6. Lahtchev, K. L., Batovska, D. I., St P, P., Ubiyvovk, V. M., \& Sibirny, A. A. (2008). Antifungal activity of chalcones: A mechanistic study using various yeast strains. European journal of medicinal chemistry, 43(10), 22202228.

7. Rao, Y. K., Fang, S. H., \& Tzeng, Y. M. (2009). Synthesis and biological evaluation of $3^{\prime}, 4^{\prime}, 5^{\prime}$ trimethoxychalcone analogs as inhibitors of nitric oxide production and tumor cell proliferation. Bioorganic \& medicinal chemistry, 17(23), 7909. 7914.

8. Ram, V. J., Saxena, A. S., Srivastava, S., \& Chandra, S. (2000). Oxygenated chalcones and bischalcones as potential antimalarial agents. Bioorganic \& medicinal chemistry letters, 10(19), 2159-2161.

9. Cabrera, M., Simoens, M., Falchi, G., Lavaggi, M. L., Piro, O. E., Castellano, E. E., ... \& Sagrera, G. (2007). Synthetic chalcones, flavanones, and flavones as antitumoral agents: Biological evaluation and structure-activity 
relationships. Bioorganic \& Medicinal Chemistry, 15(10), 3356-3367.

10. Ducki, S., Rennison, D., Woo, M., Kendall, A., Chabert, J. F. D., McGown, A. T., \& Lawrence, N. J. (2009). Combretastatin-like chalcones as inhibitors of microtubule polymerization. Part 1: Synthesis and biological evaluation of antivascular activity. Bioorganic \& medicinal chemistry, 17(22), 7698-7710.

11. Xia, Y., Yang, Z. Y., Xia, P., Bastow, K. F., Nakanishi, Y., \& Lee, K. H. (2000). Antitumor agents. Part 202: novel 2'-amino chalcones: design, synthesis and biological evaluation. Bioorganic \& medicinal chemistry letters, 10(8), 699-701.

12. Awala E. V., Bunu S. J., Baba H., \& Oluwadiya J. O. (2019). Synthesis, Characterization, antimicrobial and anti-inflammatory properties of 4-methoxy, 4, 6-diphenyl-2-thiopyrimidine and epoxide derivatives of chalcones. Sch Acad J Pharm. ISSN 2320-4206 (Online), DOI: 10.21276/sajp.2019.8.8.9, pg. 436-442.

13. Patel, R. N., Patel, P. V., Desai, K. R., Purohit, P. Y., Nimavat, K. S., \& Vyas, K. B. (2012).
Synthesis of new heterocyclic schiff base, thiazolidinone and azetidinone compounds and their antibacterial activity and anti-hiv activities. Heterocyclic Letters, 2(1), 99-105.

14. Patel, R. N., Nimavat, K. S., Vyas, K. B., \& Patel, P. V. (2011). Synthesis on study of 2-methyl-5nitro-n-(4-(3-(5-substituted-4, 5-dihydroisoxazol3 -yl) phenoxy) phenyl) benzenesulfonamide and their antimicobial activity. Der Pharma Chemica, 3(6), 334-340.

15. Patel, R. N., Patel, K. S., Chhasatia, M. R., Baser, I., (2015). Study on Synthesis of Novel Chalcone Their Antimicrobial Activity. Journal Club for Pharmaceutical Sciences (JCPS), 2(I), 20-27.

16. Bonev, B., Hooper, J., \& Parisot, J. (2008). Principles of assessing bacterial susceptibility to antibiotics using the agar diffusion method. Journal of antimicrobial chemotherapy. 61(6):1295-1301.

17. Ere, D., Dode, E., \& Usifoh, C. O. (2018). Synthesis and Antibacterial Activity of 4-Methoxy Phenyl Propenone Chalcones. Scholars Academic Journal of Pharmacy (SAJP), 7(6): 280-283. 